\title{
BASIC PRINCIPLES IN THE CORRECTION OF SEVERE SCOLIOTIC DEFORMITIES USING PEDICLE SCREW FIXATION
}

\author{
PRINCÍPIOS BÁSICOS PARA CORRECÃO DE DEFORMIDADES ESCOLIÓTICAS GRAVES \\ USANDO FIXAÇÃO COM PARAFUSOS PEDICULARES
}

\section{PRINCIPIOS BÁSICOS PARA CORRECCIÓN DE DEFORMIDADES ESCOLIÓTICAS GRAVES USANDO FIJACIÓN CON TORNILLOS PEDICULARES}

\author{
Andrey Baklanov', Sergey Kolesov², llya Shavyrin ${ }^{3}$, Andrey Panteleyev²
}

1. Center of Spine Pathology and Neurosurgery, Republic of Bashkortostan, Russia.

2. N.N. Priorov Central Institute of Traumatology and Orthopedics, Department of Spinal Pathology, Moscow, Russia.

3. Scientific and Practical Center for Medical Care for Children with Developmental Defects of the Craniofacial Region and Congenital Diseases of the Nervous System, Moscow, Russia.

\begin{abstract}
Objective: To determine the effectiveness of surgical treatment of patients with idiopathic scoliosis who have severe spinal deformity, using either all pedicle screw or hybrid constructs. Methods: A retrospective analysis of the results of treatment of 34 patients aged 15 to 27 years with severe scoliosis, operated on using pedicle screws. A comparison group consisted of 22 patients who were operated on using hybrid constructs. Patients from both groups were compared according to the following parameters: pre/postoperative Cobb angle, mobility according to the traction test, global sagittal/frontal balance, apical vertebral rotation, operative time, intraoperative blood loss, number of instrumented vertebrae, and loss of correction within 24 months. Results: In group A (pedicle screw fixation) compared to group B (hybrid spinal fixation), patients had better results in the following parameters: postoperative correction was $48 \%$ and $41 \%$, apical vertebral rotation decreased from $78^{\circ}$ to $55^{\circ}(30 \%)$ and from $74^{\circ}$ to $59^{\circ}(21 \%)$, correction of global frontal/sagittal balance from $39 / 25 \mathrm{~mm}$ to $14 / 12 \mathrm{~mm}(64 \% / 52 \%)$ and $35 / 26 \mathrm{~mm}$ to $16 / 15 \mathrm{~mm}(55 \% / 43 \%)$ between treatment groups, respectively. These results suggest a better trunk balance and greater postoperative correction in patients submitted to the all pedicle screw fixation. Smaller values were found for loss of correction of the major curve, and there was a slight increase in thoracic kyphosis in the postoperative period (24 months) $3.8 \% / 4.3 \%$ in group A vs. $6.2 \% / 7.5 \%$ in group B, indicating greater reliability and stability of the metal with the «all screw» fixation. This was a Level III retrospective comparative study. Conclusion: All the pedicle screw constructs enabled better postoperative correction, derotation, global sagittal and frontal balance, as well as a shorter fixation, compared to hybrid fixation of the spine. Level of Evidence III, Retrospective comparative study.
\end{abstract}

Keywords: Osteotomy; Spinal injuries; Scoliosis.

\section{RESUMO}

Objetivo: Determinar a efetividade do tratamento cirúrgico de pacientes com escoliose idiopática com deformidade grave de coluna usando só parafusos pediculares ou estruturas híbridas. Métodos: Análise retrospectiva dos resultados do tratamento de 34 pacientes com idade entre 15 e 27 anos com escoliose grave, submetidos a cirurgia com parafusos pediculares. 0 grupo de comparação consistiu de 22 pacientes submetidos a cirurgia com estruturas híbridas. Os pacientes dos dois grupos foram comparados de acordo com os seguintes parâmetros: ângulo de Cobb pré e pós-operatório, mobilidade, de acordo com o teste de tração, balanço sagital/frontal global, rotação vertebral apical, tempo de cirurgia, perda sanguínea intraoperatória, número de vértebras instrumentadas e perda de correção em 24 meses. Resultados: No Grupo A (parafuso pedicular), comparado ao Grupo B (estrutura híbrida), os pacientes tiveram resultados melhores nos seguintes parâmetros: correção pós-operatória de $48 \%$ vs. $41 \%$, rotação vertebral apical de $78^{\circ}$ para $55^{\circ}(30 \%)$ vs. $74^{\circ}$ para $59^{\circ}(21 \%)$, balanço sagital/frontal global de 39/25 mm para 14/12 mm (64\%/52\%) e 35/26 mm para 16/15 mm (55\%/43\%) entre os grupos de tratamento, respectivamente. Esses resultados sugerem melhor balanço do tronco e maior correção pós-operatórios nos pacientes submetidos à fixação com parafusos pediculares. Verificaram-se valores menores de perda de correção da curva principal e também um ligeiro aumento da cifose torácica no período pós-operatório (24 meses) de 3,8\% para 4,3\% no Grupo A vs. 6,2\% para 7,5\% no Grupo B, o que indica maior confiabilidade e estabilidade do metal com fixação "só com parafuso". Este é um estudo retrospectivo comparativo de Nível III. Conclusão: Todas as estruturas com parafusos pediculares possibilitaram melhor correção pós-operatória, desrotação, balanço sagital e frontal global, além de fixação mais curta em comparação com a fixação híbrida da coluna vertebral. Nível de evidência III, Estudo retrospectivo comparativo.

Descritores: Osteotomia; Traumatismo da coluna vertebral; Escoliose.

\section{RESUMEN}

Objetivo: Determinar la efectividad del tratamiento quirúrgico de pacientes con escoliosis idiopática con deformidad grave de columna, usando sólo tornillos pediculares o estructuras híbridas. Métodos: Análisis retrospectivo de los resultados del tratamiento de 34 pacientes con edad entre 15 y 27 años con escoliosis grave, sometidos a cirugía con tornillos pediculares. El grupo de comparación consistió en 22 
pacientes sometidos a cirugía con estructuras híbridas. Los pacientes de los dos grupos fueron comparados de acuerdo con los siguientes parámetros: ángulo de Cobb pre y post operatorio, movilidad, de acuerdo con el test de tracción, balance sagital/frontal global, rotación vertebral apical, tiempo de cirugía, pérdida sanguínea intraoperatoria, número de vértebras instrumentadas y pérdida de corrección en 24 meses. Resultados: En el Grupo A (tornillo pedicular), comparado al Grupo B (estructura híbrida), los pacientes tuvieron resultados mejores en los siguientes parámetros: corrección post operatoria de $48 \%$ vs. $41 \%$, rotación vertebral apical de $78^{\circ}$ para $55^{\circ}$ (30\%) vs. $74^{\circ}$ para $59^{\circ}$ (21\%), balance sagital/frontal global de $39 / 25 \mathrm{~mm}$ para $14 / 12 \mathrm{~mm}$ (64\%/52\%) y 35/26 mm para 16/15 mm (55\%/43\%) entre los grupos de tratamiento, respectivamente. Esos resultados sugieren mejor balance del tronco y mayor corrección post operatorias en los pacientes sometidos a la fijación con tornillos pediculares. Se verificaron valores menores de pérdida de corrección de la curva principal y también un ligero aumento de la cifosis torácica en el período post operatorio (24 meses) de 3,8\% para 4,3\% en el Grupo A vs. 6,2\% para 7,5\% en el Grupo B, lo que indica mayor confiabilidad y estabilidad del metal con fijación «sólo con tornillo». Este es un estudio retrospectivo comparativo de Nivel III. Conclusión: Todas las estructuras con tornillos pediculares posibilitaron mejor corrección post operatoria, desrotación, balance sagital y frontal global, además de fijación más corta en comparación con la fijación híbrida de la columna vertebral. Nivel de evidencia III, Estudio retrospectivo comparativo.

Descriptores: Osteotomía; Traumatismos vertebrales; Escoliosis.

\section{INTRODUCTION}

Severe deformities of the spine were long viewed with conservative pessimism. Nowadays, the indications for operative correction of severe deformities of the spine are being expanded, leading to significant improvements in patients' quality of life.

In the present study, scoliotic deformities with an angle of more than $90^{\circ}$ are classified as severe deformities, a category of patients with more pronounced biomechanical disorders and associated cardiopulmonary disorders., ${ }^{1,2}$

Studies evaluating the natural course of scoliosis in patients with extreme deformities of the spine have shown that the lifespan of such patients, without treatment, is dramatically reduced. ${ }^{3}$

Due to the presence of gross deformity of the chest, leading to a sharp decrease in ventilation function of the lungs and pronounced dislocation of the thoracic cavity and its organs, indication for surgical treatment of this group of patients with severe kyphoscoliosis is vital. ${ }^{4}$

The work carried out by Suk, Liljenqvist on patients suffering from idiopathic scoliosis, who underwent posterior correction and fixation of the spine with pedicle screw and hybrid instrumentation, confirmed the higher efficiency of the "all screw" constructs compared to the hybrid constructs. . $^{5}$

The optimal results of correction of frontal and sagittal balance, along with shorter periods of spinal fusion, have prompted modern spinal surgeons to give preference to "all screw" instrumentation. , $^{7,8}$

\section{Purpose of the study}

To determine the effectiveness of surgical treatment of patients with idiopathic scoliosis who have severe (Cobb angle of more than $90^{\circ}$ ) deformities of the spine, using all screw instrumentation.

\section{METHODS}

Thirty-four patients (7 male, 27 female) were under our supervision in the period 2005 to 2012. Ages ranged from 15 to 27 years, and all had idiopathic scoliosis with a major deformity curve angle of more than 90 degrees. The patients were operated on by two surgeons from the spinal surgery centers: the Center for Spine Pathology and Neurosurgery, Salavat, and the N.N. Priorov Central Institute of Traumatology and Orthopedics, Moscow.

The surgical interventions consisted of posterior correction and fixation of the spine with pedicle screws, and posterior spinal fusion. In 20 patients (58\%), the posterior stage was preceded by a front release of the intervertebral structures at the apex of the deformity, and an interbody fusion with autograft bone. The average postoperative follow-up was 2.5 years (from 3 months to 6.5 years).

Patients with follow-up of more than 2 years after surgery (22 patients, $64.7 \%$ group A) made up the study group with operated with metal implants in the period 2003 to 2010 (in fixation constructs, in addition to screws, sublaminar elements, pedicle and laminar hooks, Luque-cerclage - group B). Control radiography was performed at $3,6,12,24$, and 36 months after the intervention.
The distribution by type of spinal deformity in the patients of this study is presented in Table 1, based on to the Lenke classification. ${ }^{9}$

Most patients had type III, IV, or VI deformities (in approximately the same proportions) with a lumbar $\mathrm{C}$ modifier. In all patients, the thoracic kyphosis exceeded 40 degrees (thoracic Lenke modifier $(+)$ in 100\%) and ranged from 63 to 145 degrees. Risser's test: R4 - in 6, R5 - in 28 patients.

Preoperative examination included regular and functional radiographs of the spine (images in standard projections with the patient in the standing position, with bending radiographs, and with traction along the axis). Since the patients in this study had severe structural deformities, computed tomography and magnetic resonance imaging were performed in all patients to determine the relationship of the vertebrae in the places of the supposed location of the implants, possible stenoses of the spinal canal, and the surrounding spinal cord structures. With the aid of functional lung testing and echocardiography studies, we evaluated the compensatory capabilities of the cardiopulmonary system.

Depending on the volume of the surgical intervention, 2 groups of patients were formed: group I (14 patients, 42\%) - posterior correction and fixation of the spine with screw metal structure, posterior fusion; group II (20 patients, 58\%) - thoracotomy, anterior release of intervertebral structures at the apex of deformity (5-7 segments) and interbody fusion with local bone autograft.

The presence of a significant decrease in pulmonary and/or cardiac function (14 patients - group I) was a contraindication for ventral intervention, due to the extremely high risk of intra- and postoperative complications. These patients were operated on in a single stage, through the posterior access.

The study was approved by the N.N. Priorov Central Institute of Traumatology and Orthopedics (No. 502114). All participants signed an Informed Consent Form prior to enrolling in the study. The authors declare no conflict of interest in the performance of this work.

\section{Surgical procedure}

The aims of the surgical interventions were as follows: three-dimensional correction of the spine to attain optimal sagittal and frontal balance, ensuring long-term stability in the zone of bone block formation, and achieving cosmetic and functional effect. With extreme deformities, the main goal was to create an optimal balance of the trunk.

Intervertebral release (discectomy, excision of anterior, posterior longitudinal ligaments) was performed in 20 patients via thoracotomy

Table 1. Patient distribution by type of spinal deformity, based on the Lenke classification.

\begin{tabular}{c|c|c|c|c|c|c}
\hline $\begin{array}{c}\text { A typel } \\
\text { Lumbar } \\
\text { modifier }\end{array}$ & $\begin{array}{c}\text { I } \\
\text { (Main }\end{array}$ & $\begin{array}{c}\text { II } \\
\text { (Double }\end{array}$ & $\begin{array}{c}\text { III } \\
\text { (Double } \\
\text { Major) }\end{array}$ & $\begin{array}{c}\text { IV } \\
\text { (Triple } \\
\text { Major) }\end{array}$ & $\begin{array}{c}\text { V } \\
\text { (TL/L) }\end{array}$ & $\begin{array}{c}\text { VI } \\
\text { (TL/ L-Main } \\
\text { Thoracic) }\end{array}$ \\
\hline A & 0 & 2 & 1 & 0 & - & - \\
\hline B & 0 & 1 & 4 & 4 & - & - \\
\hline C & 2 & 3 & 6 & 6 & 0 & 5 \\
\hline
\end{tabular}


access, on 5-7 segments of the scoliotic curve apex. In the intervertebral spaces, fragments of the resected ribs were placed. The second stage occurred either immediately after the thoracotomy (under one anesthesia - 12 patients), or 7-10 days after the first stage (8 patients).

The second stage was performed via the posterior approach. After mobilizing Smith-Peterson osteotomies on 8-10 segments, we performed posterior correction and fixation of the spine with pedicle screws. In the posterior stage, the indirect derotation maneuver was used to correct the vertebral dislocation at the apex of the deformity using a short (4-6 segment) accessory para-apical rod. This derotation and distraction was then followed by a direct derotation maneuver on a long rod. (Figure 1)

A short fixation of the apical and adjacent vertebrae along the concave side of the curve was carried out on an additional rod, with the creation of an apical block (4-6 segments), distraction, and partial derotation of the short rod. (Figures 2A, D) In cases of extreme deformities (a Cobb angle of more than 120 degrees), the pronounced torsion of the vertebrae of the main curve did not allow adequate derotation, and manipulation was limited to the distraction at the fixation points of the short rod.

Next, we carried out total transpedicular-corporal implantation of the screws (inserting the pedicle screws up to the anterior longitudinal ligament), installing long rods. A short rod was brought closer to the rotated rod on the concave side using devices for transverse traction, while the apical block with the mobilized instrumented vertebrae was brought closer to the contoured rods. (Figure 2B). Then, distraction and compression were applied to the nodes of fixation of all the rods, which provided additional correction of the deformity and distributed the loads among the metal implants. (Figure 2C, 2D) Finally, if necessary, corrections were made to the rod contouring using in situ benders.

In 12 (35\%) patients we used the method of asymmetrical TLIF (Transforaminal Lumbar Interbody Fusion) in the lumbar region on one or two segments (L2-S1). Carrying out the inter-body asymmetric interbody fusion in these patients enabled the slope of the lower instrumented vertebra to be reduced, thereby correcting the frontal balance of the spine. The lordosing effect of the cage improved the sagittal profile of the vertebral column, and the more rapid formation of the lumbar fusion mass prevented fractures of the rods and screws in the lower parts of the construct. The surgical intervention was completed with decortication of the posterior elements and autograft fusion.

\section{Postoperative management of patients}

Antibacterial therapy (third generation cephalosporins) was prescribed for a period of 7-10 days after the operation, with correction of anemia (iron, erythropoiesis stimulants), water-electrolyte metabolism (colloid, crystalloid solutions), haemostatic (dicinone, aminocaproic acid), and metabolic (glucose solutions, protein solutions), and administration of analgesic therapy (epidural, anesthesia, non-steroidal anti-inflammatory drugs, opioids). The paravertebral, pleural drainage catheters were removed 24-48 hours after the intervention, with the amount of drainage less than $50 \mathrm{ml} /$ day. Activation of patients (verticalization, walking) occurred 3-5 days after the intervention. External immobilization was not required.

\section{Clinical case 1}

Patient K., 27 years old diagnosed with grade 4 idiopathic combined scoliosis. According to the radiographic images, the angle of deformity in the frontal plane was $92^{\circ}$ in the thoracic region and $73^{\circ}$ in the lumbar region. Lenke type: Double Major III C (+).

During posterior correction and fixation of the spine, Smith-Peterson osteotomy was performed at 8 levels: T4-T12. After inserting the pedicle screws and installing the contoured rods, a direct derotation maneuver was performed to transfer the curves of the rods from the frontal plane to the sagittal plane. Compression-distraction maneuvers for screws, final fixation, and posterior autografting were carried out. The patient was activated 5 days after the intervention (Figure 3), with correction of the scoliotic deformity of more than $50 \%$ (from $92 / 73^{\circ}$ in the thoracic/lumbar regions to $37 / 32^{\circ}$ degrees, respectively).

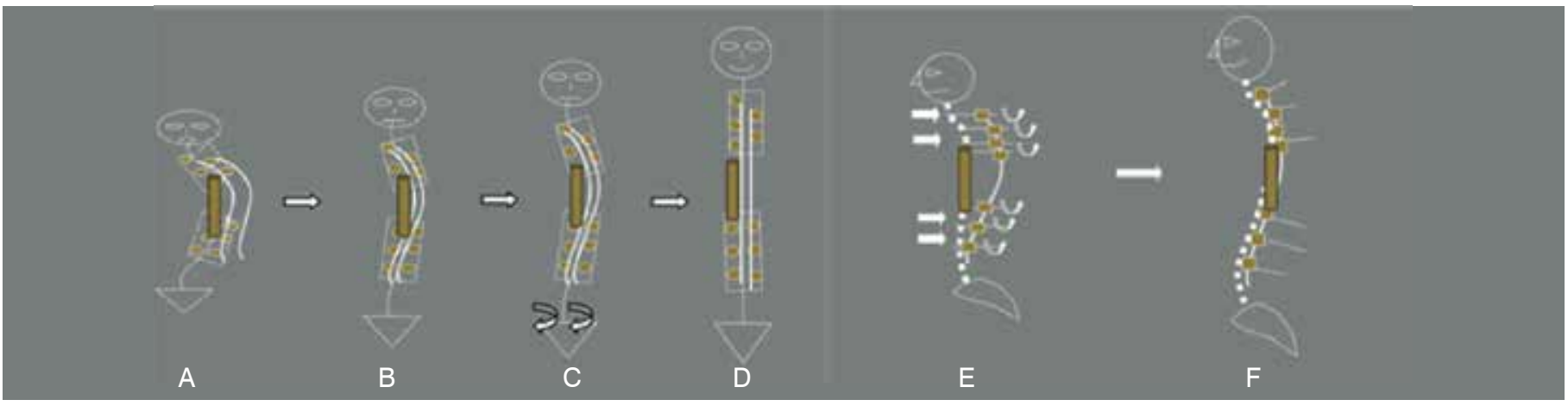

Figure 1. Depiction of the indirect derotation maneuver in the frontal (A-D) and sagittal $(E, F)$ planes (explanation in the text).

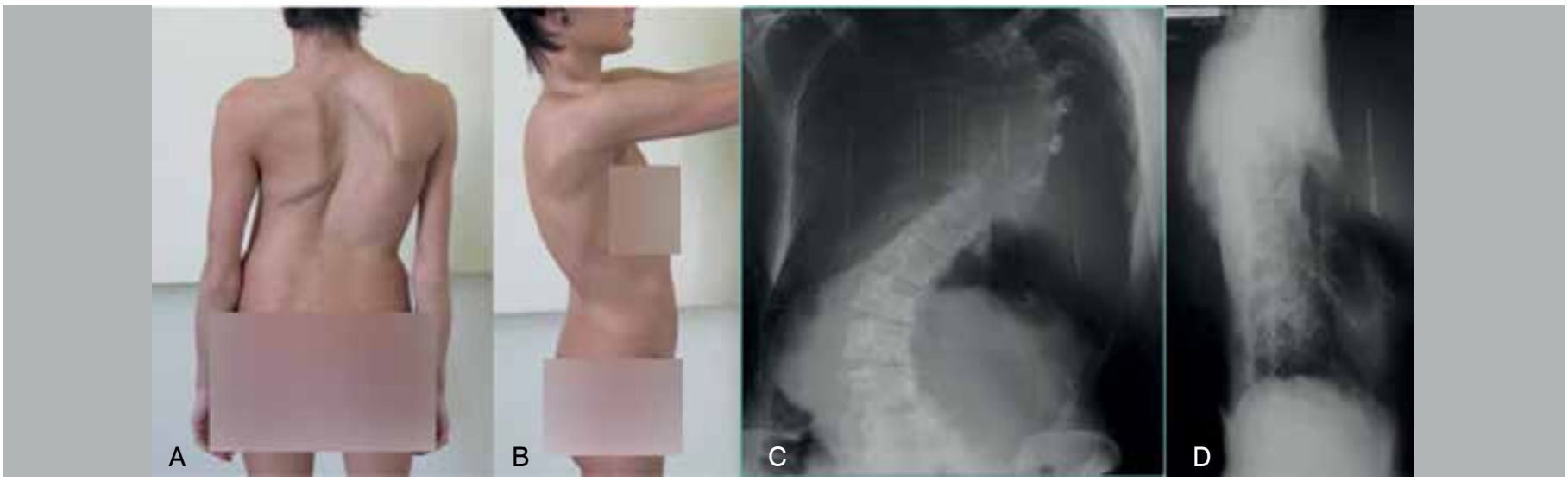

Figure 2. Appearance $(A, B)$ and radiographs of the patient $(C, D)$ upon admission. 


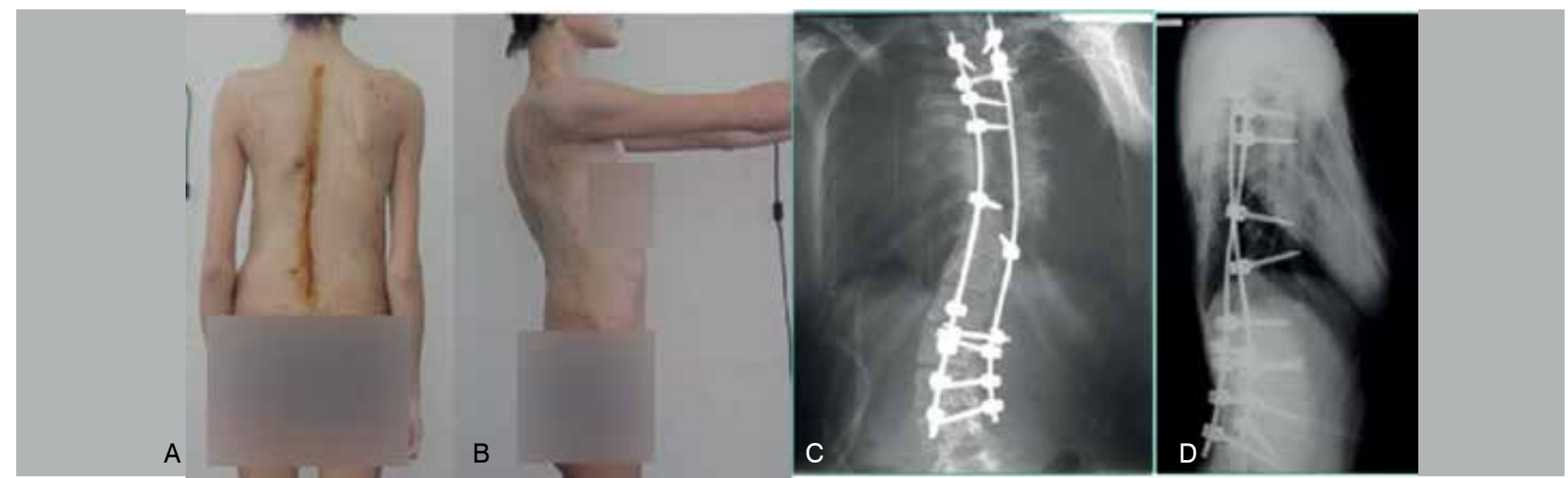

Figure 3. Appearance (A, B) and radiographs $(B, C)$ of the patient after treatment.

\section{Clinical example 2}

Patient A., 18 years old, was admitted with a diagnosis of grade 4 idiopathic thoracic right-sided scoliosis. Upon admission, the patient complained about the deformity, back pain, and shortness of breath on physical exertion. Clinically, she presented with a pronounced right-sided thoracic deformity of the spine, in the form of an acute rib hump. (Figure 4)

Radiographs demonstrated a right-sided thoracic kyphoscoliosis, with an angle of deformity of $165^{\circ}$ in the frontal plane and $120^{\circ}$ in the sagittal plane. Lenke type: Triple Major IV B (+). (Figure 5)

With functional lung testing and echocardiographic study, there was a significant decrease in VC of mixed type (40\% of the age norm), and no hemodynamic abnormalities were detected. Given the absence of decompensation of the cardiopulmonary system, it was decided to carry out surgical treatment in 2 stages.

The first stage involved a thoracotomy approach on the right, intervertebral release at T6-T11 levels, interbody spinal fusion using the rib autograft. The patient was then placed in the prone position, and the central angle was stabilized. (Figure 6)

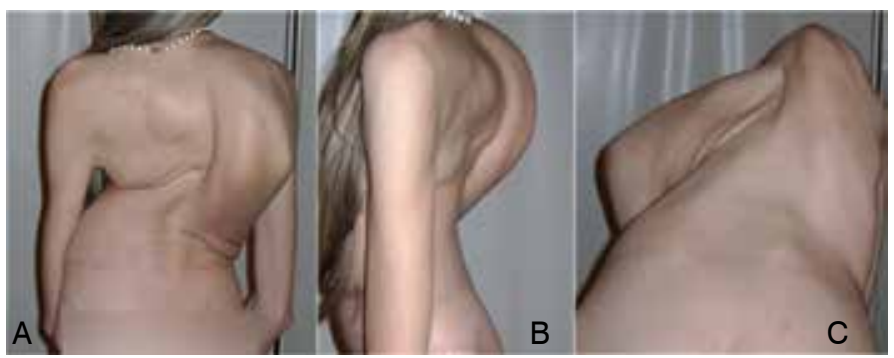

Figure 4. Appearance of the patient at admission A - back view, B - side view, C - Adams test.

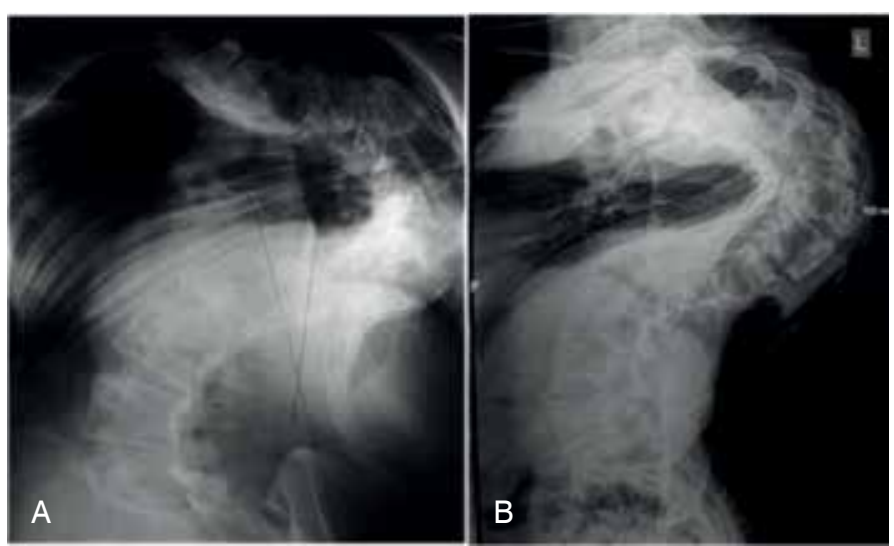

Figure 5. Radiographs of the spine of the patient in the AP (a) and lateral (b) projections
During the second stage of the surgery, which was carried out 7 days after the first, the posterior elements were exposed subperiosteally from T2 to L4. The capsules of the arcuate joints were excised, and the posterior support complex was completely freed from soft tissues. Using the Roy-Camille reference points, pedicle screws were inserted from T2 to L4. Posterior mobilization was performed using a Smith-Peterson osteotomy on 6 levels T4-T10 (including resection of spinous, articular processes, correction of the laminotomy, and excision of the yellow ligament). After achieving satisfactory mobility and contouring of the rods and instrumentation, distraction-compression maneuvers (Figure 7) were carried out. Total decortication of the laminae, facet joints and spinous processes, and local autograft fusion were also performed.

As a result of the intervention, the coronal imbalance of the trunk was successfully corrected and a good cosmetic effect was achieved. (Figures 8, 9)

\section{RESULTS}

In this study, we retrospectively evaluated the results of surgical treatment of patients with idiopathic scoliosis who underwent instrumentation using pedicle screws (Group A) and hybrid constructs (group B). In the patients in Group B, pedicle screws were used in the lumbar region and laminar hooks were used in the cranial region of the construct; the apical zone was fixed to the rods using sublaminar Luque wire (6-8 levels). In each group, 22 clinical cases were analyzed. The sex ratio was the same (male/female: 1/4.4) in both groups and average follow-up after the operation was 29 months (from 24 to 38).

The patients from both groups were compared according to the following parameters: pre/postoperative Cobb angle, mobility of deformity according to the traction test, global sagittal/frontal balance, rotation of the apical vertebra according to CT, (Figure 7) operation time, intraoperative blood loss, number of instrumented vertebrae. The loss of correction in the frontal and sagittal planes was determined from radiographs 24 months after the discharge from the hospital, and expressed as a percentage of the deformity angle after surgery.

The deformity angle was measured using the Cobb method on the radiographs in the standing position. The traction test was performed in the supine position with a traction force of up to $30 \%$ of the patient's weight. The global frontal balance was determined from the anteroposterior radiographs of the spinal column as the distance between the plumb line from the geometric center of the $\mathrm{C} 7$ vertebra and the central sacral line. The global sagittal balance was determined from the lateral radiographs as the distance between the plumb line from the geometric center of the $\mathrm{C} 7$ vertebra and the vertical line from the posterior edge of the L5- S1 disc. If the plumb line C7 was located anteriorly of the sagittal sacral line, the global balance was regarded as positive $(+)$, and if posteriorly, it was regarded as negative (-) 


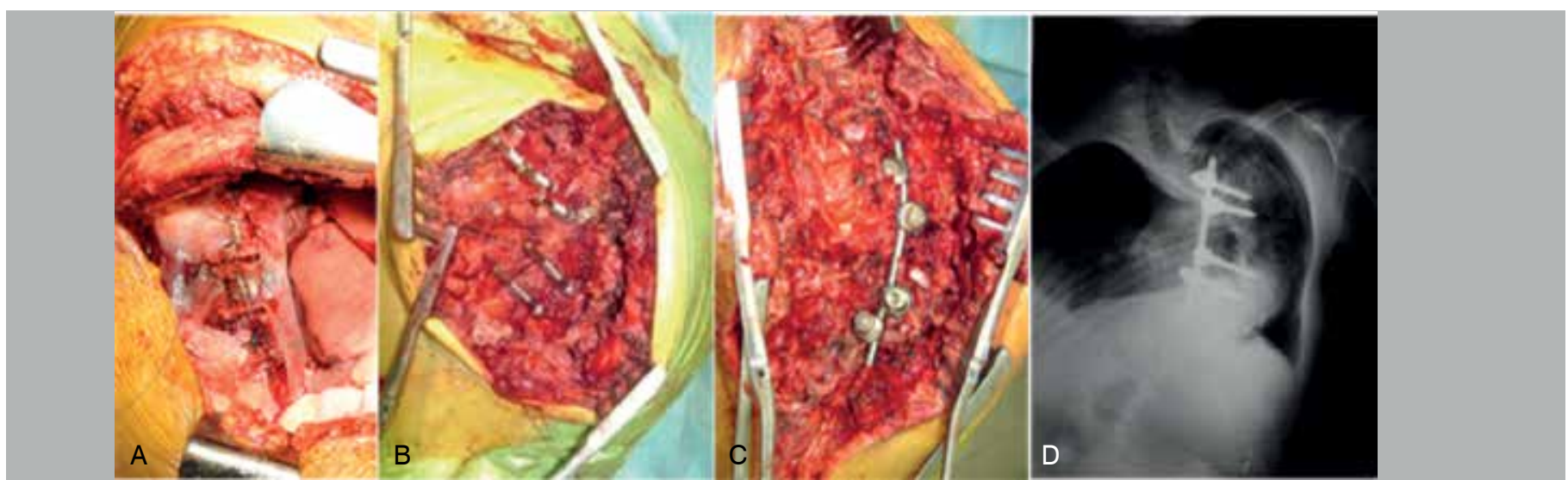

Figure 6. The first stage of surgical intervention: Thoracotomy, release of intervertebral structures at the apex of deformity (A), installation of apical short rod at T8-L1, radiograph of the spine after stage 1 (D).

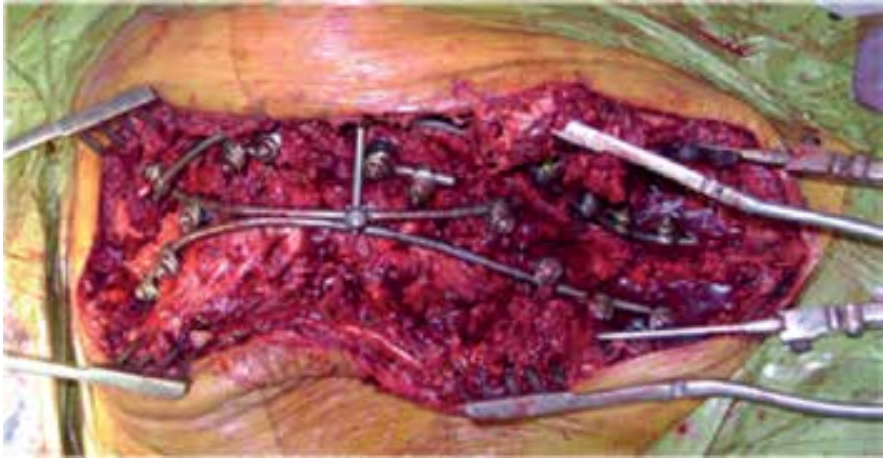

Figure 7. Intraoperative photograph: the appearance of the metal construct T2-L4. Distraction on the short rod at the deformity apex, posterior mobilization of the spine, installation of pedicle screws in the thoracic and lumbar regions, indirect derotation maneuver, instrumentation of the concave and convex side of the deformity, consecutive derotation of the short and long rods, final fixation, and posterior bone autograft fusion were carried out.
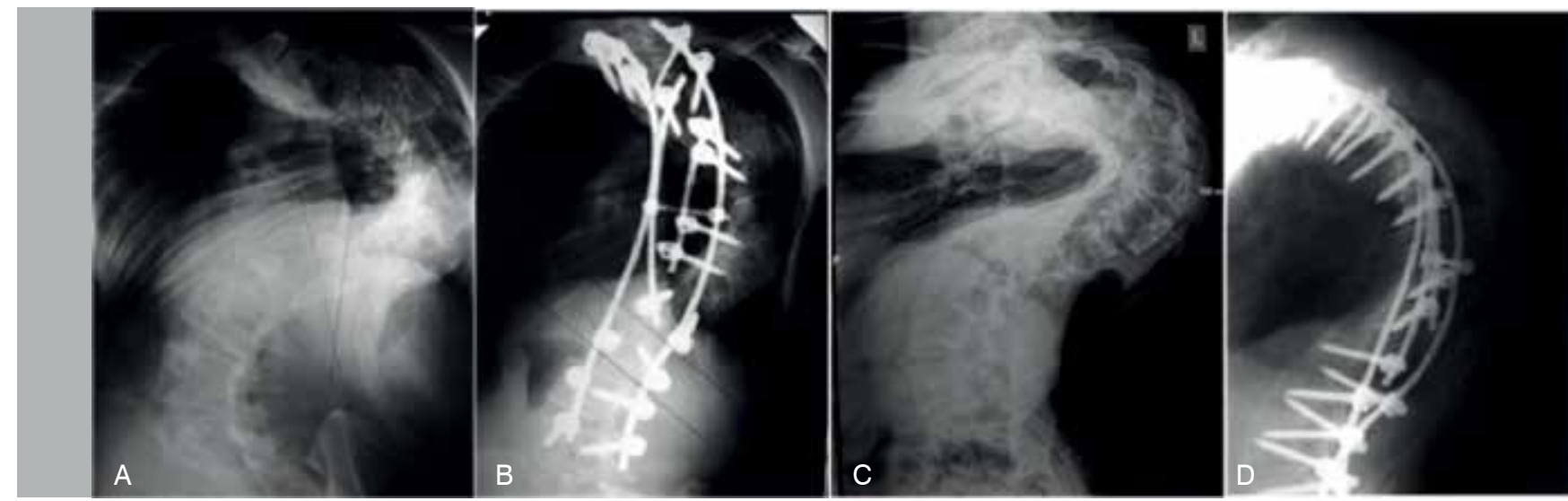

Figure 8. Radiographs of the patient before $(A, C)$ and after $(B, D)$ treatment.
The rotation of the apical vertebra was determined from computed tomography using the Aaro and Dahlborn method (Figure 10) before and after surgery. ${ }^{9}$

Loss of correction of the major curve, as well as an increase in thoracic kyphosis, were determined in both groups from radiographs 24 months after surgery.

Comparing the two study groups, we came to the conclusion that there were no differences in mean preoperative angle of deformity, mobility in the traction test, mean blood loss, and the duration of the operation (Table 2).

In group A (all pedicle screw fixation), compared with group

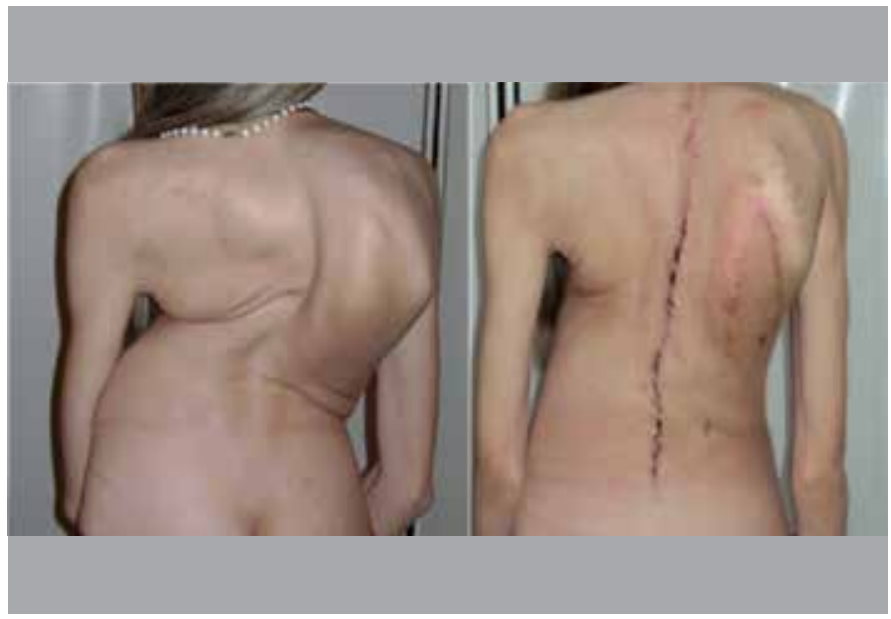

Figure 9. Appearance of the patient before (a) and after (b) surgical treatment.
B (hybrid fixation), patients had better results in the following parameters: postoperative correction was $48 \%$ and $41 \%$; rotation of the apical vertebra decreased from $78^{\circ}$ to $55^{\circ}(30 \%)$ and from $74^{\circ}$ to $59^{\circ}(21 \%)$; the global frontal/sagittal imbalance decreased from $39 / 25 \mathrm{~mm}$ to $14 / 12 \mathrm{~mm}(64 / 52 \%)$ and from $35 / 26 \mathrm{~mm}$ to $16 / 15 \mathrm{~mm}$ (55/43\%) in the two study groups, respectively. These results indicate better compensation of the trunk and a greater postoperative correction in the group of patients with all screw fixation. Smaller loss of correction of the major curve, as well as a slight increase in thoracic kyphosis in the postoperative period (after 24 months) 3.8\%/4.3\% in group $A$ compared with $6.2 \% / 7.5 \%$ in group B indicates greater 
reliability and stability of metal implants in the all screw approach. The number of fixed segments is, on average, one more in the group with hybrid fixation (13 and 14, respectively).

Instability of the metal structure, caused by the dislocation of the hooks of the upper end of the construct (Figure 11) was observed in 3 (13.6\%) patients from Group B within 8 to 22 months after surgery; in group $A$ there were no complications associated with instability of the metal implants.

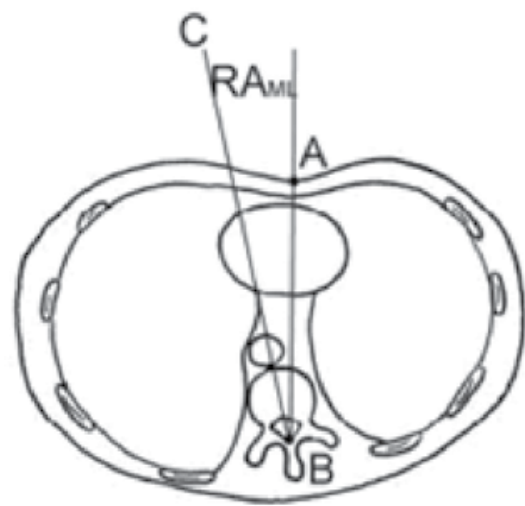

Figure 10. Determination of the angle of rotation of the apical vertebra (Aaro-Dahlborn method). The angle is formed by the lines AB and BC. Diagram courtesy of Lam et al. ${ }^{11}$
Table 2. Comparative table of groups of patients with pedicle screw (A) and hybrid (B) fixation of the spine.

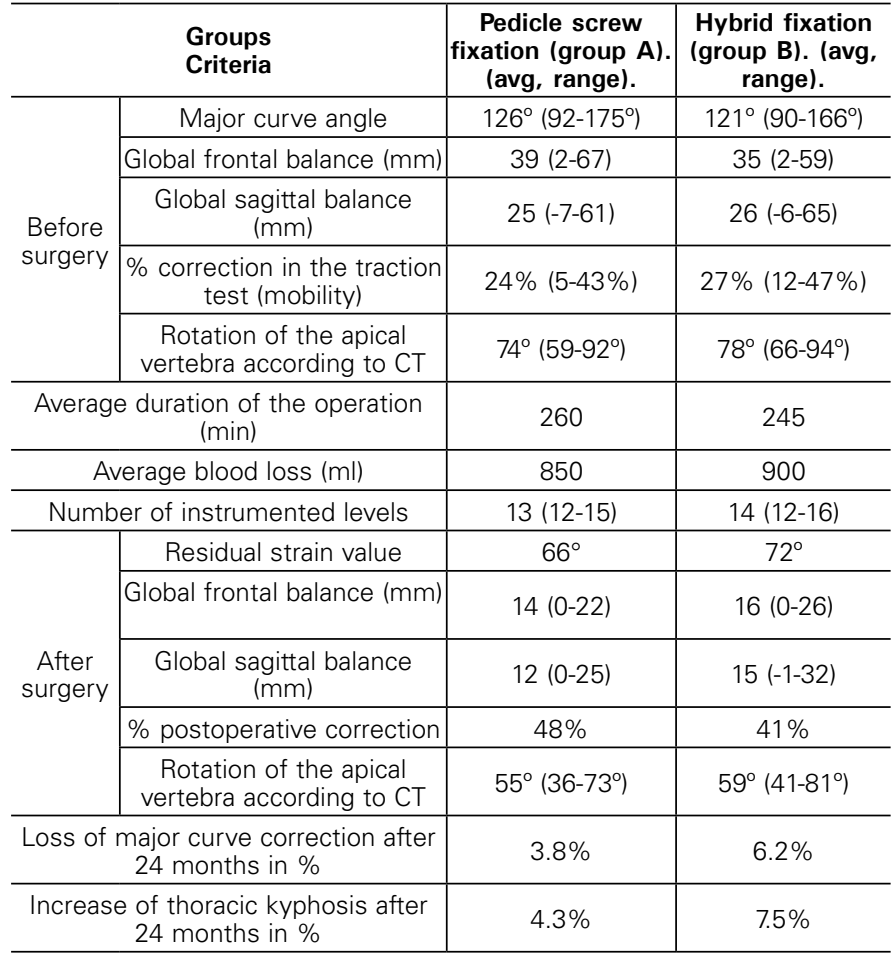

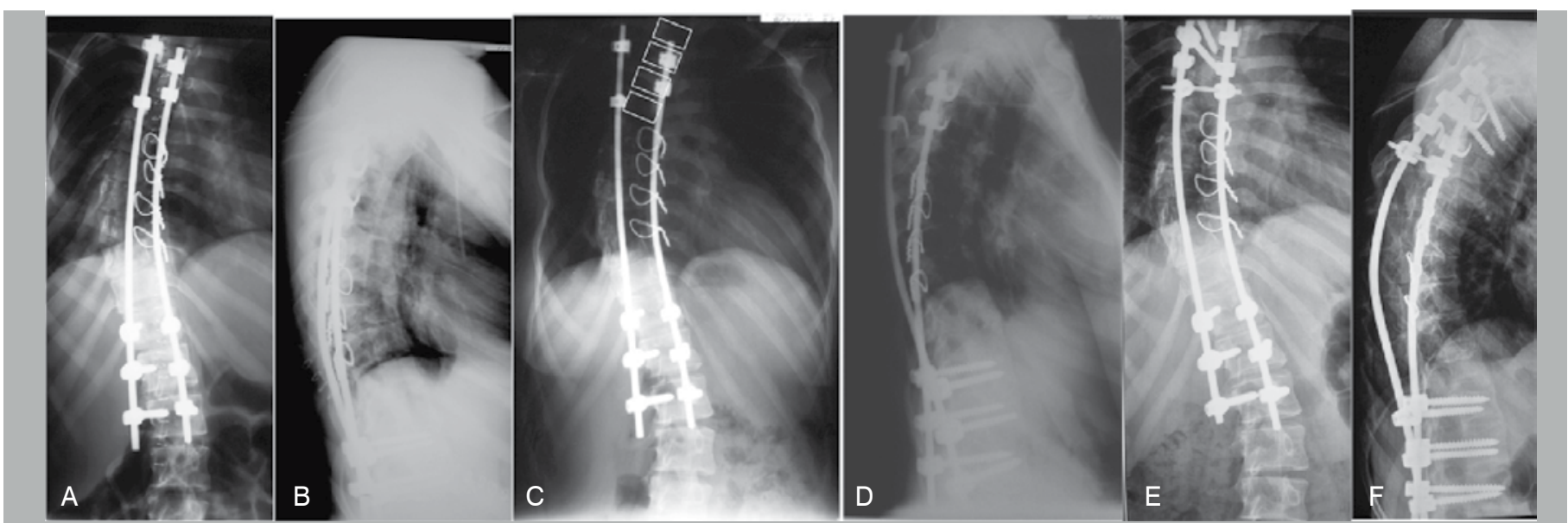

Figure 11. Radiographs after surgery (A, B) with hybrid metal construct. Dislocation of the sublaminar hooks 14 months after surgery (C, D). Radiographs after replacing the dislocated hooks with pedicle screws (E, F).

\section{DISCUSSION AND CONCLUSIONS}

Patients with severe deformities of the spine represent a difficult category of patients in need of reliable stabilization of the spinal column. The number of repeated (revision) interventions on the spine, conducted due to instability of metal structures, is associated with the highest complication risks and should be minimized. The tendency to increase the use of pedicle screw fixation in the treatment of spine deformities and the displacement of laminar systems is dictated by the need for a higher efficiency of posterior stabilization, which enables better results to be achieved in terms of eliminating trunk imbalance, obtaining postoperative correction, and reducing the number of postoperative complications caused by implant instability.

In the present study, it was revealed that according to the Lenke classification, among patients with severe deformities, types III, IV, VI with the C lumbar modifier and hyperkyphosis prevailed.

A significant reduction in cardiopulmonary function (42\%) was a contraindication for anterior intervention, and these patients were operated on in one stage, via the posterior approach.

In our opinion, the optimal surgical approach in the category of patients with severe deformities is an indirect derotation maneuver with correction and stabilization of scoliosis, which is most effective with the use of one or more apical rods.

The use of all pedicle screw constructs compared to hybrid fixation of the spine enables better postoperative correction, scoliotic curve derotation, global sagittal and frontal balance, as well as a shorter fixation. The reliability of pedicle screw fixation has been demonstrated by the smaller values for loss of correction and increase in thoracic kyphosis in the postoperative period, and by the absence of complications caused by implant instability.

All authors declare no potential conflict of interest related to this article. 
CONTRIBUTION OF THE AUTHORS: Each author made significant individual contributions to this manuscript. AB, SK and IS were the main contributors to the drafting of the article and contributed to the surgical procedures and data evaluation. IS and AP (orcid) provided extensive help in the material processing, editing of the text, literature search, and review of manuscript.

\section{REFERENCES}

1. Lowe TG, Betz RR, Clement DH, et al. An analysis of anterior versus posterior instrumented fusion for thoracic adolescent idiopathic (AIS) curves 70-80 degrees: are there advantages of one over the other? SRS 39th Annual Meeting Scientific: Program and Abstracts. Buenos Aires, 2004. p. 2.

2. Luhmann SJ, Lenke LG, Kim YJ, Bridwell KH, Schootman M. Thoracic adolescent idiopathic scoliosis curves between 70 degrees and 100 degrees: is anterior release necessary? Spine (Phila Pa 1976). 2005;30(18):2061-7.

3. Weiss HR, Karavidas N, Moramarco M, Moramarco K. Long-Term Effects of Untreated Adolescent Idiopathic Scoliosis: A Review of the Literature. Asian Spine J. 2016 Dec;10(6):1163-1169. Epub 2016 Dec 8.

4. Mayer O, Campbell R, Cahill P, Redding G. Thoracic Insufficiency Syndrome. Curr Probl Pediatr Adolesc Health Care. 2016 Mar;46(3):72-97.

5. Liljenqvist UR, Halm HF, Link TM. Pedicle screw instrumentation of the thoracic spine in idiopathic scoliosis. Spine (Phila Pa 1976). 1997;22(19):2239-45
6. Suk SI, Lee CK, Kim WJ, Chung YJ, Park YB. Segmental pedicle screw fixation in the treatment of thoracic idiopathic scoliosis. Spine (Phila Pa 1976). 1995;20:1399-405.

7. Brown CW. Spinal instrumentation techniques. In: Rosemont, IL: Scoliosis Research Society; 1998.

8. Lee SM, Suk SI, Chung ER. Direct vertebral rotation: a new technique of three-dimensional deformity correction with segmental pedicle screw fixation in adolescent idiopathic scoliosis. Spine (Phila Pa 1976). 2004;29(3):343-9.

9. Lenke LG, Betz RR, Bridwell KH, Clements DH, Harms J, Lowe TG, et al. Intraobserver and interobserver reliability of the classification of thoracic adolescent idiopathic scoliosis. J Bone Joint Surg Am. 1998;80(8):1097-106.

10. Aaro S, Dahlborn M. Estimation of vertebral rotation and the spinal and rib cage deformity in scoliosis by computer tomography. Spine (Phila Pa 1976). 1981;6(5):460-7.

11. Lam GC, Hill DL, Le LH, Raso JV, Lou EH. Vertebral rotation measurement: a summary and comparison of common radiographic and CT methods. Scoliosis. 2008;3:16. 